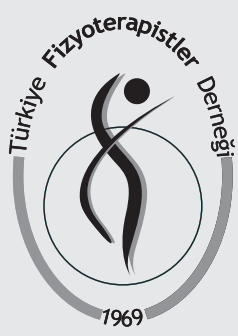

ISSN:1300-8757 • e-ISSN: 2148-0109

\section{Türk Fizyoterapi ve Rehabilitasyon Dergisi}

$201829(1) 39-45$

Mustafa Ertuğrul YAŞA, PT Sibel AKSU YILDIRIM, PhD, $P T^{2}$

1 Yıldırım Beyazıt University, Faculty of Health Sciences, Department of Physiotherapy and Rehabilitation, Ankara, Turkey.

2 Hacettepe University, Faculty of Health Sciences, Department of Physiotherapy and Rehabilitation, Ankara, Turkey.

İletişim (Correspondence):

Mustafa Ertugrul YAŞA, PT Yıldırım Beyazıt University, Faculty of Health Sciences,

Department of Physiotherapy and Rehabilitation, 06010 Ankara, Turkey

Phone: +90-312324 1555 ext. 1938

E-mail:mer_tugrul@hotmail.com

Sibel AKSU YILDIRIM / E-mail: sibelaksu@yahoo.com

Geliş Tarihi: 04.08.2017 (Received) Kabul Tarihi: 30.11 .2017 (Accepted)

\title{
BODY COMPOSITION AND ITS RELATIONSHIP WITH MOTOR PERFORMANCE IN NEUROMUSCULAR DISEASES
}

\author{
ORIGINAL ARTICLE
}

\section{ABSTRACT}

Purpose: Increased fat mass and decreased muscle mass affect patient's motor performance during slowly progressive neuromuscular diseases (NMDs). The purpose of this study was to investigate the effects of body composition on motor performance in adult patients with NMDs.

Methods: Twenty-six patients and 26 age-matched healthy participants were included in this cross-sectional study. Body composition was assessed using a bioelectrical impedance analyzer, and the motor performance was determined using a manual muscle testing, and timed performance was evaluated using climbing ten stairs, walking $10 \mathrm{~m}$, wearing a t-shirt, supine up tests, and functional level using Motor Function Measurement (MFM) scale.

Results: There was no difference between the patients and the controls in terms of age, height, weight, and body composition ( $p>0.05$ ). There was no correlation between body composition and timed performance tests for controls. In patients, the body mass index (BMI), fat mass (FM), and fat percentage (\%FM) were correlated with the time of climbing 10 stairs ( $r=0.631, r=0.693$, $r=0.718$, respectively) and supine up time $(r=0.493, r=0.643, r=0.621$, respectively) $(p<0.05)$. Ten meter walking time was correlated with \%FM $(r=0.496)$ and fat free mass $(r=-0.475, p<0.05)$. The MFM score was related with BMI ( $r=-0.425), F M(r=-0.503)$ and \%FM $(r=-0.586, p<0.05)$. Total lower extremity muscle strength was correlated with FM $(r=-0.456)$ and \%FM $(r=-0.550)$ in patients $(\mathrm{p}<0.05)$.

Conclusion: The results of the study showed that body composition might be a factor affecting motor performance in adult patients with NMDs. Preventive strategies should be considered from the early stages of the disease.

Key Words: Body Composition; Motor Performance; Neuromuscular Disease.

\section{NÖROMUSKÜLER HASTALIKLARDA VÜCUT KOMPOZISYONU ILE MOTOR PERFORMANS ILIŞKISi}

\section{ARAȘTIRMA MAKALESI}

\section{öz}

Amaç: Yavaş ilerleyen nöromüsküler hastalıklarda (NMH), hastalığın seyri boyunca azalan kas kütlesi ve artan yağ kütlesi hastaların motor performanslarını etkilemektedir. Bu çalışmanın amacı erişkin NMH'lerde vücut kompozisyonunun motor performans üzerine etkilerini araştırmaktı.

Yöntem: Bu kesitsel çalışmaya 26 hasta ve benzer yaştaki 26 sağlıklı birey dâhil edildi. Vücut kompozisyonu, bioelektrik empedans analizörü; motor performans, manuel kas testi; süreli performans testleri, 10 basamak merdiven çıkma, 10 m yürüme, t-shirt giyme ve yüzüstü yatıştan ayağa kalkma ve Motor Fonksiyon Değerlendirme Ölçeği (MFD) ile değerlendirildi.

Sonuçlar: Yaş, boy uzunluğu, vücut ağırlığı ve vücut kompozisyonu ölçümleri açısından gruplar arasında fark bulunmadı $(p>0,05)$. Sağlıklılarda süreli performans testleri ile vücut kompozisyonu arasında ilişki bulunmazdı. Hastalarda vücut kütle indeksi (VKi), yağ kütlesi (FM) ve yağ yüzdesi (\%FM) sonuçları 10 basamak merdiven çıkma süresi (sırasıyla $r=0,631, r=0,693, r=0,718$ ) ve yüzüstü pozisyondan ayağa kalkma süresi ile ( $r=0,493, r=0,643, r=0,621)$ iliş̧kili bulundu $(p<0,05)$. Hastalarda 10 m yürüme süresi, \%FM ( $r=0,496)$ ve yağsız vücut ağırlığı $(r=-0,475)$ ile ilişkiliydi. MFD skoru, VKi $(r=-0,425)$, FM $(r=-0,503)$ ve \%FM $(r=-0,586)$ ile ilişki gösterdi. Alt ekstremite toplam kas kuvveti, FM $(r=-0,456)$ ve \%FM $(r=-0,550)$ ile ilişkili bulundu $(p<0,05)$.

Tartışma: Çalışmamızın sonuçları, erişkin NMH'larda vücut kompozisyonunun hastaların motor performansını etkileyebilecek faktörlerden biri olduğunu göstermektedir. Hastalığın erken dönemlerinden itibaren koruyucu yaklaşımların göz önünde bulundurulması gerektiğini ifade etmektedir.

Anahtar Kelimeler: Vücut Kompozisyonu; Motor Performans; Nöromusküler Hastalıklar. 


\section{INTRODUCTION}

The most prominent effects of neuromuscular diseases (NMDs) are seen in muscular function. Muscular weakness and lack of muscle durability, which lead to problems in functional ability and limit the mobility of patients. Patients with NMDs mostly experienced these problems (1).

Obesity/overweight, which is caused by increased body fat index is another common problem in these patients in addition to the motor function problems. Although there are some theories to explain the mechanism of high obesity/overweight risk in these patients, most of the studies indicated that it is a result of the imbalance between calorie intakes and burn off. Another critical reason for obesity/overweight in NMDs is muscle fiber dystrophy, which is characterized by fibrosis and infiltration of adipose tissue $(2,3)$. Along with the increased fat index and decreased muscle mass which hinder patients from active movements, it is clear that the mobility of patients is significantly limited.

Physical disability and limitations are the principal problems that cause overweight or obesity in the modern society. Studies on body composition, which have been conducted with both males and females with different activity levels, showed that obesity/ overweight and the increase of body fat index lead to physical limitations $(4,5)$. Obesity/overweight is determined by body mass index (BMI), which is very easy to use and common in clinical settings. The BMl is not a comprehensive measurement for NMDs because chosen method should provide detailed information about body composition parameters such as fat mass (FM), fat-free mass (FFM) and fat percentage (\%FM) for monitoring natural history of the course of the disease. Bioelectrical impedance analysis (BIA) is an easily accessible body composition analysis method, which has no side effects on the patient, and most importantly it provides considerably detailed and easily interpretable information (6).

It is essential to know the underlying causes of body composition changes and loss of muscle mass, which occur in the progressive process of the disease to prevent them. A few recent studies, which investigated the factors that affecting motor performance in NMDs, have shown the negative impacts of the changes in the body composition on motor performance (7-9). However, there was no comprehensive study, investigate the relationship between body composition and motor performance in adult patients with NMDs.

We hypothesized that high body composition would associate with low functional outcomes in adult patients with NMDs. The purpose of this study is to examine the effect of the body composition on motor performance in adult patients with NMDs.

\section{METHODS}

This study had a cross-sectional study design. A total of 52 individuals, 26 patients diagnosed with NMDs (eight Limb-Girdle Muscular Dystrophy, six Facioscapulohumeral Muscular Dystrophy, five Becker Muscular Dystrophy, four Myotonic Dystrophy, and three Mitochondrial Muscular Dystrophy) (12 females and 14 males) were included. Twenty-six healthy individuals ( 10 females and 16 males) served as the control group. Inclusion criteria were set as: diagnosed with one of the slowly progressive NMDs, being able to communicate with the research staff efficiently, and reading and signing the written consent form. Participants were excluded if they were not able to stand and walk by themselves, and had an additional problem that could affect neuromuscular system function.

\section{Measurements}

The measurements that performed by the same physiotherapist for both groups and were divided into two parts as motor performance and body composition measurements. Patients were frequently asked if they felt tired. The proper rest intervals were given as much, if needed, during the measurements.

\section{Body Composition Measurement}

Tanita Body Composition Analyzer (TBF 300 M) (Tanita Corporation of America, Inc. Illinois, USA) is a bioelectrical impedance analyzer, leg-to-leg pressure contact system. It was used to determine body composition parameters such as weight (kg), BMI, FFM, FM, and \% FM (10). The obtained BMI data were categorized according to World Health Organization classification (11). 


\section{Motor Performance Measurements}

Muscle Strength Measurement: A total of 14 muscle groups were assessed using manual muscle testing (MMT) (Table 1). We graded muscles from 0 (Total paralyze) to 10 (Normal), which is typically used in NMDs trials and studies according to Kendall's "10 point" scale (12). The measured muscle groups were shoulder horizontal adductors, elbow extensors, and trunk flexors in the supine position, and shoulder extensors, knee flexors, trunk extensors, and hip extensors in the prone position. Hip abductors were evaluated in lying on side position, and knee extensors, hip flexors, shoulder flexors, shoulder abductors, elbow flexors, shoulder horizontal abductors were assessed in sitting position. The total values of the upper extremity (TUE), lower extremity (TLE), and trunk muscle strength were calculated by adding the values of muscles from upper extremity, lower extremity and trunk muscles in the data collection section (12).

Timed Performance Tests: Four timed performance tests which were climbing 10 standard stairs, walking previously measured $10 \mathrm{~m}$ distance in the usual pace, wearing a sleeveless t-shirt that was put on a table in front of the patients and the supine up test, which the patients were instructed to stand up from the supine position on a mat were used. Patients could rest 5 min between each performance. They were instructed to do these activities as their routine daily life and the duration of the activities was recorded (13).

\section{Functional Level}

Motor Function Measurement Scale (MFM): The MFM a special test for NMDs, which was used to determine the functional level of the participants. The test included 32 tasks in eight different positions. Each task was separately rated according to the patient's independence degree. The scale consisted of 32 different tasks and the highest score was 96. The scoring system in MFM was: (a) cannot start the task or keep starting position: 0 point; (b) starts the task but cannot complete: 1 point; (c) completes the task slowly and with compensations, but unable to carry out the task utterly: 2 points, and (d) completes the task in the standard pattern: 3 points (14).

\section{Statistical Analysis}

Statistical analysis was performed using SPSS software, version 22 (Chicago, IL, USA). The distribution characteristics of the variables were examined using visual (histogram, probability graphs) and analytical method (Shapiro-Wilk's test). Numerical variables with normal distribution were shown with mean \pm standard deviation. Student $t$ test was used to determine the differences of body composition and motor performance and Chi-square test was performed to investigate the differences of BMI groups according to World Health Organization (WHO) classification between patients and controls. Besides, Spearman's correlation coefficients were used in the evaluation of the relationships between body composition and motor performance. Statistical significance was set at $p<0.05$.

Table 1: Characteristics and Body Composition Measurements.

\begin{tabular}{|l|c|c|c|}
\hline Characteristics & $\begin{array}{c}\text { NMD } \\
\text { Mean } \pm \text { SD }\end{array}$ & $\begin{array}{c}\text { Control } \\
\text { Mean } \pm \text { SD }\end{array}$ & p \\
\hline Age (years) & $30.73 \pm 10.06$ & $29.92 \pm 9.64$ & 0.776 \\
\hline Height (cm) & $167.92 \pm 9.39$ & $171.04 \pm 6.98$ & 0.181 \\
\hline Weight (kg) & $66.62 \pm 13.91$ & $67.46 \pm 8.55$ & 0.794 \\
\hline BMI (kg/m $)$ & $23.60 \pm 4.48$ & $23.09 \pm 2.71$ & 0.194 \\
\hline FM (kg) & $16.07 \pm 8.46$ & $13.20 \pm 6.13$ & 0.149 \\
\hline \%FM & $23.26 \pm 10.67$ & $19.32 \pm 8.63$ & 0.157 \\
\hline FFM (kg) & $50.59 \pm 10.31$ & $39.74 \pm 5.93$ & \\
\hline
\end{tabular}

NMD: Neuromuscular Disorders, BMI: Body Mass Index, FM: Fat Mass, FFM: Fat Free Mass. 
Table 2: Patient and Control groups' Body Mass Index Characteristics according to WHO Classification of Body Mass Index.

\begin{tabular}{|l|l|c|c|c|c|c|}
\hline \multirow{2}{*}{ BMI } & \multirow{2}{*}{ Nutritional Status } & \multicolumn{2}{|c|}{ Patients } & \multicolumn{2}{c|}{ Controls } \\
\cline { 2 - 5 } & & $\mathbf{n}$ & $\%$ & $\mathbf{n}$ & $\%$ \\
\hline$<\mathbf{1 8 . 5}$ & Underweight & 6 & $23.07 \%$ & 3 & $11.53 \%$ \\
\hline $\mathbf{1 8 . 5 - 2 4 . 9}$ & Normal Weight & 8 & $30.76 \%$ & 15 & $57.69 \%$ \\
\hline $\mathbf{2 5 . 0 - 2 9 . 9}$ & Pre-obesity & 11 & $42.30 \%$ & 8 & $30.76 \%$ & 0.203 \\
\hline $\mathbf{3 0 . 0}-\mathbf{3 4 . 9}$ & Obesity Class I & 1 & $3.84 \%$ & 0 & 0 \\
\hline $\mathbf{3 5 . 0 - 3 9 . 9}$ & Obesity Class II & 0 & 0 & 0 & 0 \\
\hline$>\mathbf{4 0}$ & Obesity Class III & 0 & 0 & 0 & 0 \\
\hline
\end{tabular}

WHO: World Health Organization, BMI: Body Mass Index.

\section{RESULTS}

The comparison of characteristics, body composition measurements and motor performance values are shown in Table 1, Table 2, and Table 3. According to our results, the patients had similar characteristics with the control group regarding their age, height, weight and body composition measurement results ( $p>0.05$ ) (Table 1 and Table 2 ).

There were no differences in groups for TUE, yet the other motor performance measurement results of the patients were significantly higher than the control groups' $(p<0.05)$ (Table 3$)$.

The correlation between body composition, motor performance and functional level for patients are given in Table 4. The TLE was significantly correlated with $\mathrm{FM}(r=-0.456, p=0.019)$ and $\% \mathrm{FM}(r=-$ $0.550, p=0.004)$. Climbing 10 stairs time was significantly correlated with $\mathrm{BMI}(r=0.631, p=0.001)$, FM $(r=0.693, p<0.001)$, and \%FM $(r=0.718$, $\mathrm{p}<0.001)$. There was a significant correlation between $10 \mathrm{~m}$ walking time and \%FM ( $r=0.496$, $p=0.010)$ and FFM ( $r=-0.475, p=0.014)$. The time of supine up was significantly correlated with BMI $(r=0.493, p=0.027), F M(r=0.643, p=0.002)$, and $\% F M(r=0.621, p=0.003)$. Additionally, MFM score was significantly correlated with BMI $(r=-0.493$, $p=0.030)$, FM ( $r=-0.503, p=0.009)$ and \% FM ( $r=-$ 0.586, $p=0.002$ ) (Table 4).

The correlation between body composition mea-

Table 3: Motor Performance Results in Neuromuscular Disorders Patients and Controls.

\begin{tabular}{|c|c|c|c|c|}
\hline \multicolumn{2}{|c|}{ Parameters } & $\begin{array}{c}\text { NMD } \\
\text { Median (IQR 25-75) }\end{array}$ & $\begin{array}{c}\text { Control } \\
\text { Median (IQR 25-75) }\end{array}$ & $\mathbf{p}$ \\
\hline \multirow{3}{*}{$\sum_{\Sigma}^{\models}$} & TUE & 40.0 (32.99-40.0) & $40.0(38.00-40.0)$ & 0.128 \\
\hline & TLE & $39.65(31.65-44.32)$ & $48.0(45.32-50.0)$ & $<0.001^{*}$ \\
\hline & Trunk Muscles & $7.83(6.66-9.66)$ & $10.0(9.0-10.0)$ & $<0.001^{*}$ \\
\hline \multirow{4}{*}{ 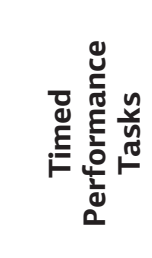 } & Climbing 10 Stairs & $8.30(6.50-12.23)$ & $5.71(4.82-6.65)$ & $<0.001^{*}$ \\
\hline & Walking 10 m & $8.39(7.58-9.77)$ & $5.97(5.50-7.0)$ & $<0.001^{*}$ \\
\hline & Wearing T-shirt & $7.22(6.42-8.0)$ & $4.23(3.64-5.34)$ & $<0.001^{*}$ \\
\hline & Supine Up & $4.20(3.0-6.70)$ & $3.00(2.71-3.75)$ & $0.008^{*}$ \\
\hline \multicolumn{2}{|c|}{ MFM score } & $86.0(79.0-90.0)$ & - & - \\
\hline
\end{tabular}

*p<0.05. NMD: Neuromuscular Disorders, MMT: Manual Muscle Testing, TUE: Total Upper Extremity, TLE: Total Lower Extremity, MFM: Motor Function measurement Scale. 
Table 4: Correlations between Body Composition and Motor Performance Measurements in Neuromuscular Disorders Patients.

\begin{tabular}{|c|c|c|c|c|c|c|c|c|c|}
\hline \multirow{2}{*}{\multicolumn{2}{|c|}{$\begin{array}{l}\text { Motor Performance } \\
\text { Parameters }\end{array}$}} & \multicolumn{2}{|c|}{ BMI } & \multicolumn{2}{|c|}{ FM } & \multicolumn{2}{|c|}{$\% F M$} & \multicolumn{2}{|c|}{ FFM } \\
\hline & & $\mathbf{r}$ & $\mathbf{p}$ & $\mathbf{r}$ & $\mathbf{p}$ & $\mathbf{r}$ & $\mathbf{p}$ & $\mathbf{r}$ & $\mathbf{p}$ \\
\hline \multicolumn{2}{|l|}{ Age } & 0.510 & $0.008^{*}$ & 0.618 & $0.001^{*}$ & 0.532 & $0.005^{\star}$ & 0.166 & 0.419 \\
\hline \multirow{3}{*}{$\sum$} & TUE & -0.009 & 0.966 & -0.126 & 0.540 & -0.165 & 0.419 & 0.139 & 0.499 \\
\hline & TLE & -0.370 & 0.062 & -0.456 & $0.019^{*}$ & -0.550 & $0.004^{*}$ & 0.226 & 0.266 \\
\hline & Trunk Muscles & 0.099 & 0.631 & -0.185 & 0.366 & -0.374 & 0.060 & 0.300 & 0.136 \\
\hline \multirow{4}{*}{ 总 } & Climbing 10 Stairs & 0.631 & $0.001^{*}$ & 0.693 & $<0.001^{*}$ & 0.718 & $<0.001^{*}$ & -0.184 & 0.400 \\
\hline & Walking $10 \mathrm{~m}$ & 0.110 & 0.593 & 0.332 & 0.097 & 0.496 & $0.010^{*}$ & -0.475 & $0.014^{*}$ \\
\hline & Wearing T-shirt & -0.341 & 0.088 & -0.205 & 0.315 & -0.040 & 0.846 & -0.288 & 0.153 \\
\hline & Supine Up & 0.493 & $0.027^{*}$ & 0.643 & $0.002^{*}$ & 0.621 & $0.003^{*}$ & -0.306 & 0.190 \\
\hline \multicolumn{2}{|c|}{ MFM score } & -0.425 & $0.030^{*}$ & -0.503 & $0.009^{*}$ & -0.586 & $0.002^{\star}$ & 0.119 & 0.563 \\
\hline
\end{tabular}

*p<0,05. r=Spearman r. NMD: Neuromuscular Disorders, MMT: Manual Muscle Testing, TUE: Total Upper Extremity, TLE: Total Lower Extremity, BMI: Body Mass Index, FM: Fat Mass, FFM: Fat Free Mass, MFM: Motor Function Measurement Scale.

surements and motor performance results for control groups are given in Table 5. Only two of the motor performance measurements were related to body composition measurements results. Trunk muscle strength was correlated with $F M(r=0.523$, $p=0.006)$ and $\% F M(r=0.486, p=0.012)$ and the time of supine up was correlated with FFM $(r=-0.408$, $\mathrm{p}=0.038$ ) (Table 5).

As seen in Table 4 and Table 5, age was correlated with body composition measurements in both patients and control group (for patients: BMI ( $r=0.510, p=0.008), F M \quad(r=0.618, p=0.001)$, $\% F M(r=0.532, p=0.005)$; for control group: $B M I$ $(r=0.424, p=0.031), F M(r=0.507, p=0.008)$, and $\% F M(r=0.476, p=0.014)$.

\section{DISCUSSION}

The most important finding of this study was the body composition changes could be a factor that might affect the motor performance in NMDs. The finding showed that the motor performance, which

Table 5: Correlation Results between Body Composition and Motor Performance Measurements in Control Group.

\begin{tabular}{|c|c|c|c|c|c|c|c|c|c|}
\hline \multirow{2}{*}{\multicolumn{2}{|c|}{$\begin{array}{l}\text { Motor Performance } \\
\text { Parameters }\end{array}$}} & \multicolumn{2}{|c|}{ BMI } & \multicolumn{2}{|c|}{ FM } & \multicolumn{2}{|c|}{$\% F M$} & \multicolumn{2}{|c|}{ FFM } \\
\hline & & $\mathbf{r}$ & $\mathbf{p}$ & $\mathbf{r}$ & $\mathbf{p}$ & $\mathbf{r}$ & p & $\mathbf{r}$ & $\mathbf{p}$ \\
\hline \multicolumn{2}{|l|}{ Age } & 0.424 & $0.031^{*}$ & 0.507 & $0.008^{*}$ & 0.476 & $0.014^{*}$ & -0.142 & 0.490 \\
\hline \multirow{3}{*}{$\sum_{\Sigma}^{\mathfrak{E}}$} & TUE & 0.319 & 0.112 & -0.101 & 0.625 & -0.180 & 0.379 & 0.348 & 0.081 \\
\hline & TLE & 0.301 & 0.135 & 0.063 & 0.762 & -0.001 & 0.997 & 0.178 & 0.385 \\
\hline & Trunk Muscles & 0.183 & 0.371 & 0.523 & $0.006^{*}$ & 0.486 & $0.012^{*}$ & -0.124 & 0.460 \\
\hline \multirow{4}{*}{ 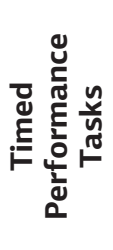 } & Climbing 10 Stairs & -0.082 & 0.689 & -0.083 & 0.686 & -0.045 & 0.829 & -0.008 & 0.971 \\
\hline & Walking $10 \mathrm{~m}$ & 0.072 & 0.727 & 0.066 & 0.748 & 0.112 & 0.585 & -0.221 & 0.278 \\
\hline & Wearing T-shirt & 0.154 & 0.452 & -0.171 & 0.403 & -0.158 & 0.440 & 0.333 & 0.097 \\
\hline & Supine Up & 0.007 & 0.972 & 0.237 & 0.244 & 0.257 & 0.205 & -0.408 & $0.038^{*}$ \\
\hline
\end{tabular}

${ }^{*}$ < <0.05. r=spearman r. MMT: Manual Muscle Testing, TUE: Total Upper Extremity, TLE: Total Lower Extremity, BMI: Body Mass Index, FM: Fat Mass, FFM: Fat Free Mass. 
was already under the constraint of the progressive course of NMDs might also negatively be affected by the changes in the body composition. Therefore, patients' body composition measurements should be followed from the first stages of the disease and precautions should be taken against the risk factors.

According to our results, although it was not significant in control group, FM, \%FM, and BMI were positively correlated with timed performance tasks and negatively correlated with TUE and MFM score in the patients. It is possible that normal muscle performance of healthy individuals may compensate negative effects of increment of body composition parameters. Conversely, patients with NMDs may fail to prevent negative impacts of these increases in body composition that may lead to an acceleration of functional muscle fibers loss since patients could not adopt this increment as healthy individuals could.

According to the literature, various body composition analysis methods are available such as Magnetic Resonance Imaging, Computed Tomography, Dual Energy X-Ray Absorptiometry, BIA, and skinfold measurement (15). Previous studies investigating the relationship between these body compositional analyses found that BIA has been coherent with the other analysis methods $(6,16)$. In our study, body composition was measured using $\mathrm{BIA}$, and it was chosen because it is cost-efficient, has no side effects or disorders on the patient, is easily interpretable, and most importantly provides considerably detailed information to generate several links from each body composition parameter to muscle performance.

It was previously defined in the literature that body composition is related to aging in both healthy and diseased conditions. Reduced physical activity, metabolic and endocrine system changes and chronic diseases are the most common reasons for $(17,18)$. In our study, although it is more significant in patients; a strong correlation between aging and body composition results were found in both control and patient groups. As a clinical outcome, it might show that the patients who already have musculoskeletal and cardiopulmonary problems are also at the risk of obesity due to the aging process.
According to the previous studies that focus on body composition in NMDs, the \%FM value is more responsible for the changes in body composition for NMDs compared to the other body composition outcomes (19-21). Our study was coherent with the other studies in the literature that the correlations were presented with \%FM value rather than other body composition parameters in this study. It is reasonable to assume that \%FM can be chosen to follow the patient's body composition levels rather than BMI, FM, and FFM values in adults with NMDs.

Although some other studies focused on motor performance and body composition in $\operatorname{NMDS}(7,8)$, this study was distinguished because it focused not only on body composition's relationship with the muscle strength measurements but also on its correlation with functional measurements. A major limitation of our study was that our patient group did not involve individuals with various motor performance and functional levels. That may explain why the correlations between body composition and muscle strength were found only with TLE in our study. Another limitation was that the study was performed without a power analysis to determine an exact number of study population. There has no curative therapeutic method for NMDs despite the very promising recent developments. However, several previous studies have concluded that it substantially affects the patient's quality of life, which causes a need to develop methods to relieve the symptoms caused by the disease and maintain the functional capacities of patients (22). Although we did not found a novel treatment procedure for NMDs, our findings should not be disregarded since every small piece of knowledge about the disease is very important and invaluable.

All these results illustrate an example of the importance of body composition that affects motor performance in adult patients with NMDs. It should be considered for future trials that body composition changes should be a predictor of patient's motor functional status.

In conclusion, our study findings showed the necessity of the prevention strategies, which should be included in the treatment program from the early stages of the disease to reduce the adverse effects of changes in body composition. 
Sources of Support: No external source of funding or specific grant from any funding agency in the public, commercial, or not-for-profit organization was received.

Conflict of Interest: The author declared no potential conflicts of interest concerning the research, authorship, and publication of this article.

Ethical Approval: This study protocol was approved by the Hacettepe University Ethics Board (Turkey), (LUT 08/43-27).

Informed Consent: Each participant was provided with a written consent form before any study-related procedure.

Acknowledgements: The authors would like to thank Professor Yavuz Yakut and physiotherapist Özge Çoban for their valuable contributions in revising the manuscript. The study was performed at Hacettepe University, Faculty of Health Sciences, Department of Physiotherapy and Rehabilitation, Neurological Rehabilitation Unit.

\section{REFERENCES}

1. Kilmer DD, Zhao HH. Obesity, physical activity, and the metabolic syndrome in adult neuromuscular disease. Phys Med Rehabil Clin N Am. 2005;16(4):1053-62.

2. McCrory MA, Kim H-R, Wright NC, Lovelady CA, Aitkens S, Kilmer DD. Energy expenditure, physical activity, and body composition of ambulatory adults with hereditary neuromuscular disease. Am J Clin Nutr. 1998;67(6):1162-9.

3. Weil E, Wachterman M, McCarthy EP, Davis RB, O'day B, lezzoni $\mathrm{LI}$, et al. Obesity among adults with disabling conditions. JAMA. 2002;288(10):1265-8.

4. Zoico E, Di Francesco V, Guralnik J, Mazzali G, Bortolani A, Guariento $\mathrm{S}$, et al. Physical disability and muscular strength in relation to obesity and different body composition indexes in a sample of healthy elderly women. Int J Obes Relat Met Disord. 2004;28(2):234-41.

5. Simoes EJ, Kobau R, Kapp J, Waterman B, Mokdad A, Anderson L. Associations of physical activity and body mass index with activities of daily living in older adults. J Community Health. 2006;31(6):453-67.

6. Erselcan T, Candan F, Saruhan S, Ayca T. Comparison of body composition analysis methods in clinical routine. Ann Nutr Metab. 2000;44(5-6):243-8.
7. Sedehizadeh S, Brook JD, Maddison P. Body composition and clinical outcome measures in patients with myotonic dystrophy type 1. Neuromuscul Disord. 2017;27(3):286-9.

8. Miscione MT, Bruno F, Ripamonti C, Nervuti G, Orsini R, Faldini C, et al. Body composition, muscle strength, and physical function of patients with Bethlem myopathy and Ullrich congenital muscular dystrophy. Sci Word Jo. 2013;2013:152684.

9. Vohra RS, Lott D, Mathur S, Senesac C, Deol J, Germain S, et al. Magnetic resonance assessment of hypertrophic and pseudo-hypertrophic changes in lower leg muscles of boys with Duchenne muscular dystrophy and their relationship to functional measurements. PloS One. 2015;10(6):e0128915.

10. Kyle UG, Bosaeus I, De Lorenzo AD, Deurenberg P, Elia M, Gómez JM, et al. Bioelectrical impedance analysis-part I: review of principles and methods. Clin Nutr. 2004;23(5):1226-43.

11. World Health Organization. Obesity: preventing and managing the global epidemic. (WHO) Technical Report Series 894. Geneva: WHO. 2000.

12. Kendall FP, McCreary EK. Muscles, testing and function. Brit J Sports Med. 1984;18(1):25.

13. Bushby K, Finkel R, Birnkrant DJ, Case LE, Clemens PR, Cripe L, et al. Diagnosis and management of Duchenne muscular dystrophy, part 1: diagnosis, and pharmacological and psychosocial management. Lancet Neurol. 2010;9(1):77-93.

14. İnal HS, Tarakçi E, Tarakçi D, Aksoy G, Kiliç SM, Beşer H, et al. Turkish version of the Motor Function Measure Scale (MFM-32) for neuromuscular diseases: a cross-cultural adaptation, reliability, and validity study. Turk J Med Sci. 2017;47(6):1826-33.

15. Lemos T, Gallagher D. Current body composition measurement techniques. Curr Opin Endocrinol Diabetes Obes. 2017;24(5):310-4.

16. Thomson R, Brinkworth GD, Buckley JD, Noakes M, Clifton PM. Good agreement between bioelectrical impedance and dual-energy $\mathrm{X}$-ray absorptiometry for estimating changes in body composition during weight loss in overweight young women. Clin Nutr. 2007;26(6):7717.

17. St-Onge M-P, Gallagher D. Body composition changes with aging: the cause or the result of alterations in metabolic rate and macronutrient oxidation? Nutrition. 2010;26(2):152-5.

18. Jiang Y, Zhang Y, Jin M, Gu Z, Pei Y, Meng P. Aged-related changes in body composition and association between body composition with bone mass density by body mass index in Chinese Han men over 50-year-old. PloS One. 2015;10(6):e0130400.

19. McDonald CM, Carter GT, Abresch RT, Widman L, Styne DM, Warden $\mathrm{N}$, et al. Body composition and water compartment measurements in boys with Duchenne muscular dystrophy. Am J Phys Med Rehabil. 2005;84(7):483-91.

20. Mok E, Béghin L, Gachon P, Daubrosse C, Fontan J-E, Cuisset J-M, et al. Estimating body composition in children with Duchenne muscular dystrophy: comparison of bioelectrical impedance analysis and skinfold-thickness measurement. Am J Clin Nutr. 2006;83(1):65-9.

21. Zanardi M, Tagliabue A, Orcesi S, Berardinelli A, Uggetti C, Pichiecchio A. Body composition and energy expenditure in Duchenne muscular dystrophy. Eur J Clin Nutr. 2003;57(2):273-8.

22. Oksuz C, Kilinc M, Yildirim SA. Predictors of health-related quality of life in adult ambulatory independence neuromuscular disease patients. Neurosciences (Riyadh). 2009;14(4):355-9. 